\title{
EQUILIBRIUM
}

Quarterly Journal of Economics and Economic Policy

2016 VOLUME 11 ISSUE 1, March

p-ISSN 1689-765X, e-ISSN 2353-3293

www.economic-policy.pl

Olszak, M., Pipień, M., \& Roszkowska, S. (2016). The Impact of Capital Ratio on Lending of EU Banks - the Role of Bank Specialization and Capitalization. Equilibrium. Quarterly Journal of Economics and Economic Policy, 11(1), pp. 43-59, DOI: http://dx.doi.org/10.12775/ EQUIL.2016.002

Małgorzata Olszak* University of Warsaw, Poland

Mateusz Pipień Cracow University of Economics, Poland

Sylwia Roszkowska

National Bank of Poland, Poland

\section{The Impact of Capital Ratio on Lending of EU Banks - the Role of Bank Specialization and Capitalization ${ }^{* *}$}

JEL Classification: $E 32 ; G 21 ; G 28 ; G 32$

Keywords: loan supply; capital ratio; procyclicality

\begin{abstract}
In this paper we aim to find out whether bank specialization and bank capitalization affect the relationship between loans growth and capital ratio, both in expansions and in contractions. We hypothesize that the impact of bank capital on lending is relatively strong in cooperative banks and savings banks. We also expect that this effect is nonlinear, and is stronger in "low" capital banks than in "high" capital banks. In order to test our hypotheses, we apply the two-step GMM robust estimator for data spanning the years 1996-2011 on individual banks
\end{abstract}

(C) Copyright Institute of Economic Research

Date of submission: March 20, 2015; date of acceptance: September 9, 2015

* Contact: corresponding author molszak@wz.uw.edu.pl, Faculty of Management, University of Warsaw, ul. Szturmowa 1/3, 02-678 Warsaw, Poland.

${ }^{* *}$ We gratefully acknowledge the financial support provided by the Polish National Science Centre (NCN), decision no. DEC-2012/05/D/HS4/01356. This paper's findings, interpretations, and conclusions are entirely those of the authors and do not necessarily represent the views of institutions at which the authors are affiliated. 
available in the Bankscope database. Our analysis shows that lending of poorly capitalized banks is more affected by capital ratio than lending of well-capitalized banks. Loans growth of cooperative and savings banks is more capital constrained than lending of commercial banks. Capital matters for the lending activity in contractions only in the case of savings and "low" capital banks.

\section{Introduction}

The size of the effect of changes in bank capital on the extension of bank credit has been one of the most important questions of the crisis, due to the role that banks play in the economy. In the aftermath of the 2007/8 financial turmoil, Basel Committee proposed significant changes to previously accepted capital standards. The set of new rules has been named Basel III. It covers substantial increases in regulatory capital ratios and in the quality of bank capital (BIS, FSB \& IMF, 2011; BIS, 2010, 2011). These new standards are now being implemented in EU, due to formal acceptance of its rules in directive1 and in regulation2 in 2013. As the EU market is a definitely more banking sector oriented economy, it is important to extend our knowledge on the importance of bank capital for bank lending.

Although the magnitude of the effect of bank capital on bank lending in the 2007 financial crisis seemed to be a very salient question for practitioners and researchers, few recent estimates of this effect exist. Those estimates are usually focused on the US banks (Beatty \& Liao, 2011; Berrospide \& Edge, 2010; Carlson et al., 2013). Some papers investigate a sample of both EU and US banks (Gambacorta \& Marquez-Ibanez, 2011). Several papers focus on selected single countries in the EU (e.g UK: Mora \& Logan, 2011; Bridges et. al., 2014; France: Labonne \& Lame, 2014). The main message from these studies is that bank capital does indeed affect bank lending, though this impact is diversified. In a recent study Olszak, et. al. (2014b) focus on large EU banks, and test whether this diversity may be attributed to income smoothing, procyclicality of loan loss provisions, regulations and supervision. They find that loans growth of banks that have more procyclical loan loss provisions and that do not engage in income smoothing is more sensitive to capital ratios. They also find that more re-

\footnotetext{
${ }^{1}$ See DIRECTIVE 2013/36/EU OF THE EUROPEAN PARLIAMENT AND OF THE COUNCIL of 26 June 2013 on access to the activity of credit institutions and the prudential supervision of credit institutions and investment firms, amending Directive 2002/87/EC and repealing Directives 2006/48/EC and 2006/49/EC ((L 176).

2 REGULATION (EU) No 575/2013 OF THE EUROPEAN PARLIAMENT AND OF THE COUNCIL of 26 June 2013 on prudential requirements for credit institutions and investment firms and amending Regulation (EU) No 648/2012 (L 176).
} 
strictive regulations and more stringent official supervision reduce the magnitude of the effect of capital ratio on bank lending during economic downturns.

Our study makes contribution to the literature in two areas. The first consists in looking at the potential diversity of association between loans growth and capital ratio in banks differing in their specialization. The other is related to nonlinear effects of capital ratios on lending, which was tested for the US banks (see Carlson et al., 2013), but not in the EU context. In this area, we ask whether the level of capital ratio of a bank is important for the effects of bank capital on lending activity, and what the strength of this relation is.

To test our hypotheses, we apply the two-step GMM robust estimator (Blundell \& Bond, 1998) for data spanning the years 1996-2011 on individual banks available in the Bankscope database

The rest of the paper is organized as follows. Section 2 develops our hypotheses. In Section 3 we describe our sample and research design. We discuss the results and supplemental analyses in Section 4. Section 5 concludes our work.

\section{Hypotheses Development}

The role of bank specialization for procyclicality of bank capital has not been formally tested thus far. ${ }^{3}$ Some evidence in this respect, however, can be found in a study of Gambacorta \& Mistrulli (2004), who analyzed the impact of bank capital on lending of cooperative banks and commercial banks. They suggest that bank capital channel may be stronger for cooperative banks because of two features of those banks' activity. The first, is the fact that cooperative banks' balance sheets contain a larger percentage of long-term loans (which means that the balance sheet maturity transformation gap is larger, exposing them to greater interest rate risk), while their bonds issues are lower. The second explanation for the greater effect of the bank capital channel for these banks could be the local activity of these banks and thus little use of derivatives to shield the maturity transformation gap. With those characteristics, cooperative banks bear a higher cost when the interest rates are raised, and obtain a higher gain in the opposite case. However, it is also possible that the close relationships of cooperative banks with their stakeholders (e.g. cooperatives members), makes them

\footnotetext{
${ }^{3}$ Specialization is an important determinant of procyclicality of loan loss provisions (see Olszak et al, 2014a and 2016).
} 
more resilient to the business cycle fluctuations. In effect, they will lend to their borrowers irrespective of macroeconomic conditions. In contrast, commercial banks may be more responsive to external financing conditions, and therefore may be susceptible to business cycle fluctuations in the lending activity. In particular, in the case of commercial banks, the association between loans growth and capital ratio in contractions may be positive, implying that they are constrained by capital.

Following the above, we hypothesize that:

\section{H1. Commercial banks lending is less affected by capital ratios than coop-} erative banks lending.

The only sample of banks for which the effect of bank capital on lending has not been empirically tested thus far is the savings banks category. The specific feature of their activity is deposit collection and loan extension to customers - which resembles the business model of cooperative banks, especially due to the potentially large maturity transformation gap in these banks. Consequently, in the same line as cooperative banks, savings banks may be prone to interest rate risk, and thus their lending could be strongly related to capital ratios. But unlike cooperative banks, the customers of savings banks do not have so close ties with the bank. Moreover, savings banks are not operating on local markets. Therefore, they may respond to economic contractions by reducing their lending. And it is possible that the association between capital and lending in contractions will be positive.

As for the role of the level of capital ratio for the effects of the capital ratio on loans growth there are at least two possible explanations. On the one hand, Peydró (2010) suggests that due to the correlation between banks and poor quality borrowers on the cross-section, banks with lower capital may lend more on average to firms with higher risk. In contractions or during crisis times financially weaker borrowers, (e.g. companies with low level of internal finance) may need more bank financing, and thus increase the demand for credit. If these borrowers are matched with poorly capitalized banks, then at the bank level the association between capital and lending would be weak or counterintuitive, as these weaker banks are facing higher credit demand. However, as Peydró suggests, this does not mean that bank capital is not crucial, it only shows that the analysis of the role of capital at the bank and borrower level may yield biased estimates.

On the other hand, in the theoretical setting, Valencia (2008) shows that banks seek to keep some precautionary level of capital that serves them as a smoothing mechanism to avert disruptions in the supply of credit when the small shocks occur. Therefore, the question is whether the association 
between capital ratios and loans growth is larger when the capital buffer ${ }^{4}$ - i.e. the difference between the actual bank capital and the minimum capital (e.g capital adequacy ratio or internal capital requirement) is small, and whether the relationship is weak when the buffer is high.

Some previous empirical evidence suggests that when the capital ratio of a bank is closer to its minimum requirement then the bank tends to reduce its lending (Gambacorta \& Mistrulli, 2004; Kishan \& Opiela, 2006; Carslon et al., 2013). Gambacorta and Mistrulli (2004) show that Italian banks with more capital relative to minimum requirements tend to be less responsive in their lending extension to negative monetary policy shock or cyclical downturn. Kishan and Opiela (2006) investigate the effects of expansionary and contractionary monetary policy on lending of low-capital and high-capital banks and find that monetary policy has an asymmetric impact on lending, depending on whether the bank belongs to either lowcapital or high-capital sample and on the type of monetary policy applied. Their results show that the low-capital banks are adversely affected by contractionary policy, but expansionary policy is not effective in stimulating the loans growth of low-capital banks.

In a recent paper, Carlson et al. (2013) test the hypothesis that the association between capital ratios and loans growth is nonlinear. To analyze this explanation, they interact capital ratio with three indicator variables: "low" capital, "medium" capital and "high" capital banks. Their study provides strong empirical evidence in favor of a nonlinear effect. While they find that in general the capital ratio has a positive relationship with loans growth, this association is larger and statistically significant when the capital ratio is closer to the regulatory minimum requirement and becomes smaller and less significant as capital ratio increases.

Considering the results of previous studies we put forward our second hypothesis:

H2: The relationship between capital ratio and loans growth of EU banks is nonlinear.

More specifically, we expect that:

H2.1. The association between capital ratio and loans growth of EU banks is larger when the capital ratio is closer to its minimum requirement.

\footnotetext{
${ }^{4}$ More on the role of a bank's capital buffer on the risk-taking and therefore on the lending activity of the bank can be found in Borio and Zhu (2012).
} 
Beatty and Liao (2011) find that effect of the capital ratio on loans growth is strengthened during recessionary periods in the sample of publicly traded US banks. This result is further supported by Carlson et al. (2013), who found that the effect of capital ratios on loans growth rates was stronger in lending contraction relative to lending expansion. This leads us to our third hypothesis that:

H.3. The association between loans growth and the capital ratio is stronger in economic contraction in the case of "low" capital banks.

\section{Data and Research Method}

\section{Data}

We use pooled cross-section and time series data of individual banks' balance sheet items and profit and loss accounts from $27 \mathrm{EU}$ countries and country-specific macroeconomic indicators for these countries, over a period from 1996 to 2011. The balance sheet and profit and loss account data are taken from unconsolidated financials available in the Bankscope database, whereas the macroeconomic data were accessed from the EUROSTAT and the IMF web pages. We exclude from our sample outlier banks by eliminating the extreme bank-specific observations when a given variable adopts extreme values. Since most of these institutions are located in Ireland, the number of countries included in the final sample drops to 26. Based on this selection strategy, the number of banks included in our sample is 2523 (27359 observations and 26 countries).

\section{Method of Research}

The most problematic issue in the measurement of the impact of bank capital on loan extension is the identification of supply and demand factors, which affect lending activity. In particular, during recessionary periods, not only credit supply (due to bank capital and liquidity problems) may decrease, but also credit demand of households and firms may decline. This makes any identification of bank capital effects on lending in downturns difficult.

Several approaches have been used in the literature to take account of both supply side and demand side determinants of bank lending. The traditional approach is to take into account economic conditions linked to loan demand such as inflation, gross domestic product growth or unemployment 
rate (see e.g. Gambacorta \& Mistrulli, 2004; Berrospide \& Edge, 2010; Beatty \& Liao, 2011). Other papers use regional variations of bank health and economic conditions to differentiate between supply and demand effects (Hancock \& Wilcox, 1998).

The second approach consists in the application of data extracted from the national central banks lending surveys (Blaes, 2011; Del Giovane, et al., 2011, Bassett et al., 2014 and Labonne \& Lame, 2014). In this strategy, researches combine bank-level data with individual responses to the lending survey and study the dynamics of credit in Germany (Blaes, 2011), Italy (Del Giovane et al., 2011), US (Bassett et al., 2014) and French (Labonne \& Lame, 2014). These studies reveal significant contribution of bank lending surveys in disentangling credit supply shocks from demand shocks, especially during the financial crisis.

The third solution is to use a quasi experiment - which requires having data on banks affected by shock which had not been generated by a market where the bank is operating. Such an approach has been applied by Peek and Rosengren (1997), who analyzed the effects of capital shocks on the lending of the branches and subsidiaries of Japanese banks located in the United States. By focusing on the transmission of the effects of the Japanese stock market losses via the actions of Japanese bank branches and subsidiaries in the United States, Peek and Rosengren were able to isolate the credit supply effects of a fall in bank capital. In a more contemporary study Mora and Logan (2011) use losses on UK banks' loan to non-UK residents (an external shock) and see how this affected lending to UK residents.

The empirical models that addressed the question of whether a bankcapital induced credit crunch was hindering the recovery were developed in the early- and mid- 1990s in the US (see e.g. Bernanke \& Lown, 1991; Hancock \& Wilcox, 1994a,b; 1997; 1998; Peek \& Rosengren, 1995). In our study we apply contemporary adoptions of those models available in several studies (Berrospide \& Edge, 2010; Beatty \& Liao, 2011; Carlson et al., 2013; Labonne \& Lame, 2014; Bridges et al., 2014 and Olszak et al., 2014b). We apply a reduced form model, including both supply and demand side of the lending market: 


$$
\begin{aligned}
& \Delta \text { Loan }_{i, t}=\beta_{1}+\beta_{2} \text { Contraction }+\beta_{2} \text { CAP }_{i, t}+\beta_{3} \text { Contraction } * \text { CAP } P_{i, t}+ \\
& \beta_{4} \frac{D E P}{T A}_{i, t}+\beta_{5} \text { INTERBANK }_{i, t}+\beta_{6} \Delta C A P_{i, t}+\beta_{7} Q L P_{i, t}+\beta_{8} \text { size }+ \\
& \beta_{9} \Delta U N E M P L_{j, t}+\beta_{10} \sum_{j=1}^{27} \text { Country }_{j}+\beta_{11} \sum_{t=1996}^{2011} T_{t} \vartheta_{i, t}+\varepsilon_{t}
\end{aligned}
$$

where:

$i$ - the number of the bank;

$j$ - the number of country;

$t$ - time;

$\triangle$ Loan - real annual loans growth rate;

CAP - capital ratio, i.e. equity capital divided by total assets;

DEP/TA - deposits from nonfinancial customers divided by total assets;

INTERBANK - a measure of interbank market activity; it equals bank loans extended to other banks divided by deposits from banks;

DEPBANKS - deposits from banks divided by total assets;

$\triangle \mathrm{CAP}$ - annual change in capital ratio;

QLP - is quality of lending portfolio; it equals loan loss provisions divided by average loans;

size - logarithm of assets;

$\triangle \mathrm{UNEMPL}$ - annual change in unemployment rate.

In our research we focus on only one capital ratio measured as the equity capital divided by total assets. We do not include other types of capital ratios, such as capital adequacy ratio or Tier 1 capital ratio, due to the large number of missing data on these ratios in the Bankscope database.

The annual change in unemployment rate is our measure of demand for loans (Bikker \& Metzemakers, 2005; Dell'Ariccia et al., 2012).

Elements $\sum_{j=1}^{27}$ Country $_{j}$ and $\beta_{11} \sum_{t=1996}^{2011} T_{t}$ are a set of country and time dummy variables $\vartheta$ are unobservable bank-specific effects that are not constant over time but vary across banks. Finally, $\varepsilon$ is a white-noise error term.

In Table 1 we present all variables applied in our econometric model with expected impact they have on loans growth. We predict a negative coefficient on Contraction if loan supply declines during contractions for reasons other than capital and liquidity constraints (as do Beatty \& Liao, 2011, p. 7).

To test our first hypothesis, we conduct separate regressions for commercial banks, cooperative banks and savings banks. 
Table 1. Variables description and expected signs in the regressions

\begin{tabular}{|c|c|c|}
\hline $\begin{array}{c}\text { Variable } \\
\text { name }\end{array}$ & $\begin{array}{l}\text { Expected } \\
\text { sign }\end{array}$ & Basic argument \\
\hline \multicolumn{3}{|l|}{$\Delta$ loan } \\
\hline Contraction & - & $\begin{array}{l}\text { A negative coefficient on Contraction is predict- } \\
\text { ed if loan supply declines during contractions for } \\
\text { reasons other than capital and liquidity con- } \\
\text { straints }\end{array}$ \\
\hline ContractionxCAP & $+/-$ & $\begin{array}{l}\text { A positive sign is expected if banks loans } \\
\text { growth is constrained by capital in contractions, } \\
\text { a negative sign is expected otherwise. }\end{array}$ \\
\hline CAP & + & $\begin{array}{l}\text { A positive sign is expected if loans growth is } \\
\text { constrained by capital ratio. That is banks with } \\
\text { higher capital ratio will extend more loans. }\end{array}$ \\
\hline DEP/TA & + & $\begin{array}{l}\text { Banks which have more stable funding (depos- } \\
\text { its) relative to loans should be able to extend } \\
\text { loans. }\end{array}$ \\
\hline INTERBANK & $+/-$ & $\begin{array}{l}\text { A positive sign is expected if interbank deposits } \\
\text { boost liquidity of a bank, and make lending } \\
\text { easier }\end{array}$ \\
\hline$\triangle \mathrm{CAP}$ & - & $\begin{array}{l}\text { To increase capital ratio a bank must either } \\
\text { increase its capital (without changes in risk } \\
\text { weighted assets) or decrease risky loans (without } \\
\text { change in capital). }\end{array}$ \\
\hline QLP & - & $\begin{array}{l}\text { The higher the share of loan loss provisions in } \\
\text { bank loans the lower the loans growth }\end{array}$ \\
\hline Size & $+/-$ & $\begin{array}{l}\text { Large banks may benefit from too-big-to-fail } \\
\text { position and thus might isolate better adverse } \\
\text { shocks (a positive coefficient). }\end{array}$ \\
\hline$\triangle \mathrm{UNEMPL}$ & - & $\begin{array}{l}\text { Greater the unemployment rate change the lower } \\
\text { is the demand for loans, and thus the loans } \\
\text { growth is reduced }\end{array}$ \\
\hline
\end{tabular}

Source: own work.

To test our second hypothesis, we divide our banks into three subsamples: low capital, medium capital and high capital. The low capital (henceforth low cap_30) bank is a bank that has the capital ratio below 30th percentile of the distribution of the banks in the $j$-th country. The medium capital bank (henceforth medium cap_40) is a bank that has the capital ratio between the 30th and 70th percentile, and the high capital bank (henceforth high cap_30) has the capital ratio above the 70th percentile. In order to check if the results are robust to different thresholds, we additionally run separate regressions for $20^{\text {th }}$ percentile (high capital), between $20^{\text {th }}$ and $60^{\text {th }}$ (medium capital) and for above $60^{\text {th }}$ percentile (high capital). 
In order to take into account the impact of the capital ratio on loans growth in contractionary periods we include interaction term between CAP and Contraction. We expect positive association between loans growth and this interaction term only when banks feel capital constrained in contractions, and therefore do not increase their lending.

Contraction is one of our key variables. Due to the fact that there is no one dataset including information on business cycle expansions and contractions in all EU countries, we have to resort to our own identification procedure. In this procedure we follow Lenart \& Pipień (2013) approach, and apply dataset available in a study by Olszak et al. (2014b, p. 41).

Our econometric model involves explanatory variables that may be endogenous. This means that these variables are correlated with the error terms, both current and lagged. Therefore, we apply an approach that involves instrumental variables. In order to limit the possible estimation bias, we consider the system of generalized method of moments (GMM) developed by Arellano \& Bond (1991), and further developed by Blundell \& Bond (1998). We control for the potential endogeneity of bank specific variables, i.e. CAP, DEP/TA, INTERBANK, $\triangle \mathrm{CAP}$ and QLP in the two step system GMM estimation procedure, by the inclusion of up to eight lags of explanatory variables as instruments. The $\triangle$ UNEMPL, as well as the country and the time dummy variables are the only variables considered exogenous. The GMM estimator is efficient and consistent if the models are not subject to serial correlation of order two and the instruments are not proliferated. Therefore we apply the test verifying the hypothesis of absence of second-order serial correlation in the first difference residuals (ar2). We also use the Hansen's J statistic for overidentifying restrictions, which tests the overall validity of the instruments tests (see Roodman, 2009, for more details).

\section{Results}

Results using full sample of banks are given in table 2. We find evidence in favour of capital ratios impacting loans growth, as the association between loans growth and capital ratio is positive and statistically significant in the full sample of banks. Our estimates suggest that 1 percentage point increase in capital ratio results in bank loans growth of $1.01 \%$. If we take account of bank specialization, we find that cooperative and savings banks' lending is a little bit more capital constrained by the capital ratio than lending of commercial banks. This gives some empirical support to our first hypothesis (H1). 


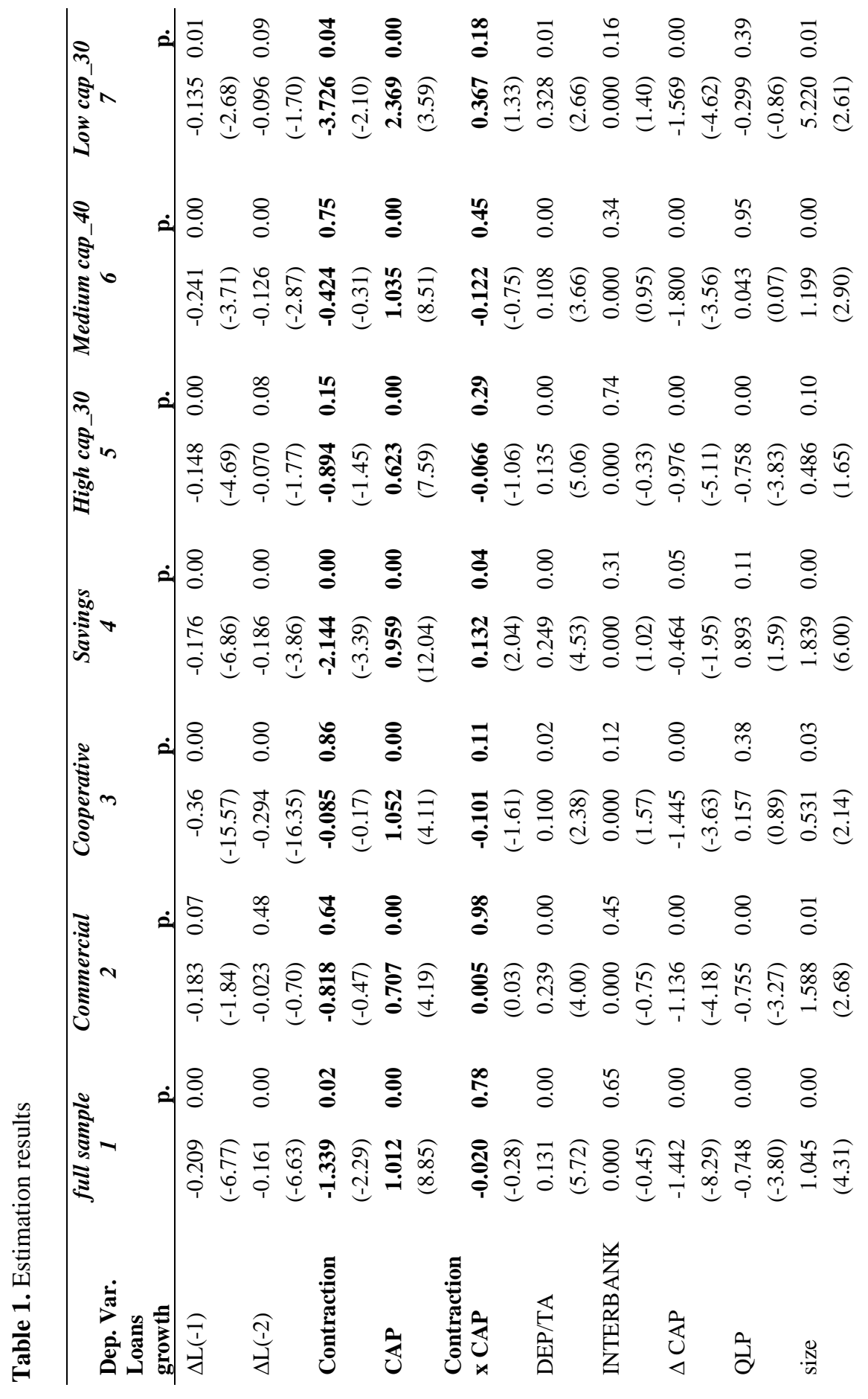




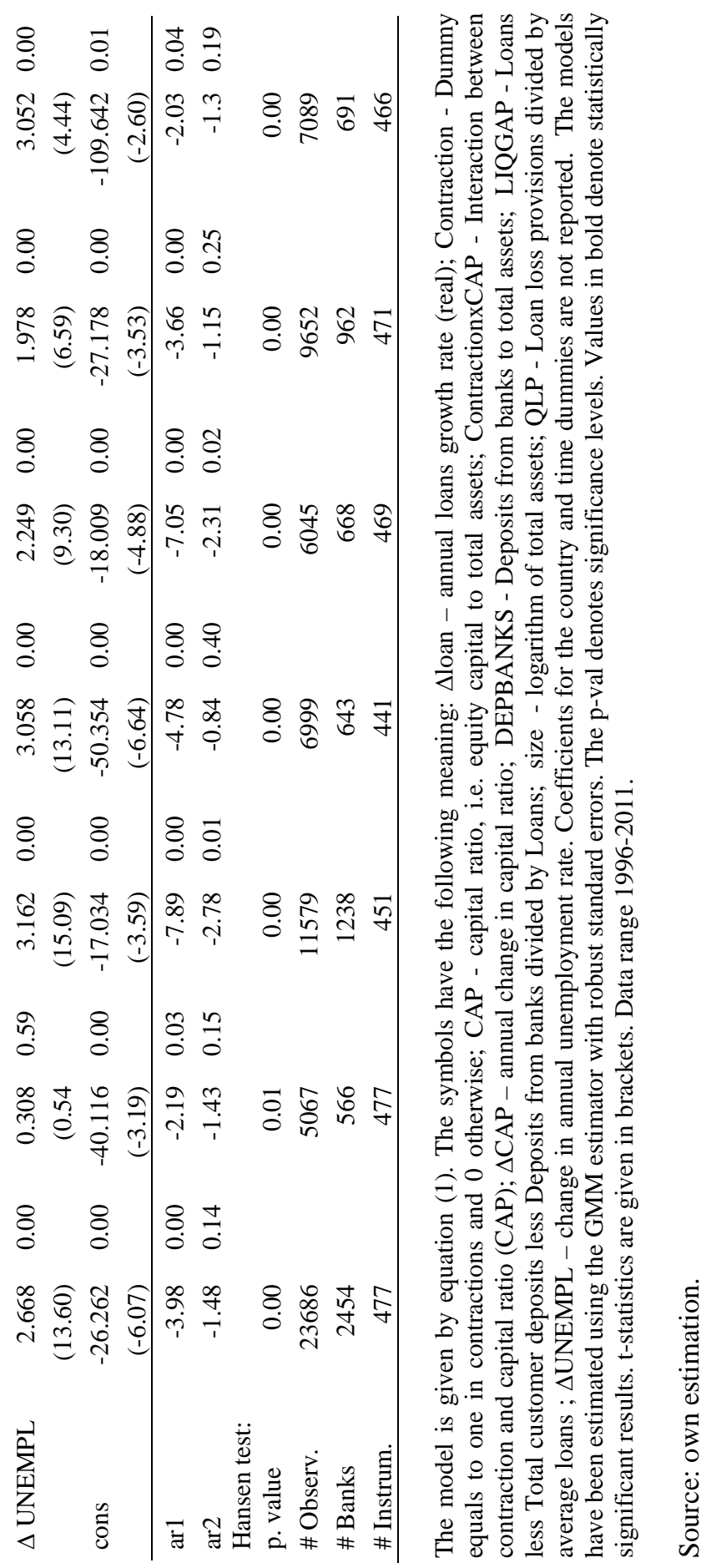


Our results, which appear in Table 2 provide strong evidence of a nonlinear effect and thus give support to hypothesis $\mathrm{H} 2$. When capital ratio of a bank is below the $30^{\text {th }}$ percentile, our estimates suggest that a 1 percentage point increase in capital ratio raises bank loans growth by 2.34 percentage points. When the capital ratio is above the $70^{\text {th }}$ percentile of its distribution, however, the estimates suggest that capital ratio has a much more modest impact on bank lending. In this sample of banks the association between loans growth and bank capital ratio is 0.62 , which means that a 1 percentage point increase in capital ratio results in $0.62 \%$ increase in loans growth.

As for the impact of bank capital on lending in contractions two types of banks seem to be capital constrained. The first group consists of savings banks. In this sample the impact of the capital ratio is positive and statistically significant, but relatively weak. The other sample includes "low capital banks, as our results suggest that the effect of capital ratio on lending in contractions is positive and strongest only in the case of "low" capital banks.

With respect to the other variables, we find that liquidity stemming from access to stable financing (measured with DEP/TA) has economically and statistically significant impact on the lending activity of all types of banks. Having said this, we must stress the fact that the impact of liquidity constraints is definitely weaker than the impact of capital ratios, as the regression coefficients on DEP/TA are definitely lower than coefficients on CAP.

Relatively poor performance of loans, as measured by loan loss provisions over average loans (QLP), but for savings banks, tends to be associated with lower loans growth rates.

Size also matters for the lending capacity of banks. On average, banks with larger assets extend more new loans, as the regression coefficient on size is positive and statistically significant. The estimated effect is the strongest in the case of "low" capital banks. In this subsample 1 percentage increase in the size variable raises the lending by $5 \%$. Generally, our findings support the view that big banks should be less prone to adjusting their credit portfolio in the event of external shocks (such as monetary policy changes or crises).

We also find that loans growth is higher when the unemployment rate is higher in all types of banks. Such results lends empirical support to the view that in the case of most banks, supply factors are more important for loans growth than demand effects. 


\section{Conclusions}

This paper investigates the existence of cross-sectional differences in the response of bank lending to bank capital in the EU, both in expansions and in contractions. Our analysis is conducted separately for banks differing in specialization and levels of capital ratio. We find that cooperative and savings banks' lending is a little bit more capital constrained by the capital ratio than lending of commercial banks. We also find that "high" capital banks can better shield their lending from contractions as well as are less capital constrained in their credit extension in expansions that "low" capital banks. The lending of poorly capitalized banks is more affected by the capital ratio than lending of well capitalized banks. Capital matters for the lending activity in contractions only in the case of savings and "low" capital banks.

All in all, these findings indicate that bank capital is a relevant determinant of lending activity. As we find that lending of well capitalized banks is less affected to changes in capital ratio, we give empirical support to contemporary changes in capital regulations exemplified in the Basel III standards.

\section{References}

Arellano, M., \& Bond, S. (1991). Some test of specification for panel data: Monte Carlo evidence and application to employment equations. Review of Economic Studies, 58.

International Monetary Fund (IMF) (2011). Macroprudential Policy Tools and Frameworks. Progress Report to G20, 27 October 2011.

Basel Committee on Banking Supervision (BCBS) (2010). Basel III: a global regulatory framework for more resilient banks and banking systems. Basel: Bank For International Settlements.

Basel Committee on Banking Supervision (BCBS) (2011). Basel III: a global regulatory framework for more resilient banks and banking systems. Basel: Bank for International Settlements.

Bassett, W. F., Chosak, M. B., Driscoll, J. C., \& Zakrajasek, E. (2014). Changes in bank lending standards and the macroeconomy. Journal of Monetary Economics, 62(6). DOI: 10.1016/j.jmoneco.2013.12.005.

Beatty, A., \& Liao, S. (2011). Do delays in expected loss recognition affect banks' willingness to lend? Journal of Accounting and Economics, 52. DOI:10.1016/j. jacceco.2011.02.002.

Beatty A., \& Liao S. (2014). Financial accounting in the banking industry: A review of the empirical literature. Jounral of Accounting and Economics, 58,. DOI:10.1016/j.jacceco.2014.08.009. 
Berger, A., Herrig, R. J., \& Szegö, G. P. (1995). The role of capital in financial institutions. Journal of Banking and Finance, 19. DOI:10.1016/03784266(95)00002-X.

Bernanke, B. S., \& Lown, C. S. (1991). The Credit Crunch. Brookings Papers on Economic Activity, 2.

Berrospide, J. M., \& Edge, R. M. (2010). The effects of bank capital on lending: What do we know? And What does it mean? International Journal of Central Banking, 6(4).

Bikker, J. A., \& Metzemakers, P. A. J. (2005). Bank provisioning behavior and procyclicality. Journal of International Financial Markets, Institutions and Money, 15. DOI:10.1016/j.intfin.2004.03.004.

Blaes, B. (2011). Bank-related loan supply factors during the crisis: an analysis based on the German bank lending survey, Number 2011, 31. Discussion Paper Series 1: Economic Studies. http://www.bundesbank.de/Redaktion/EN/Downl oads/Publications/Discussion_Paper_1/2011/2011_12_30_dkp_31.pdf?_blob= publicationFile 08.12.2014.

Blundell, R., \& Bond, S. (1998). Initial conditions and moment restrictions in dynamic panel data model. Journal of Econometrics, 87. DOI:10.1016/S03044076(98)00009-8.

Borio, C., \& Zhu, V. H. (2012). Capital Regulation, Risk-Taking, and Monetary Policy: A Missing Link in the Transmission Mechanism? Journal of Financial Stability 8. DOI:10.1016/j.jfs.2011.12.003.

Carlson, M., Shan, H., \& Warusawitharana, M. (2013). Capital ratios and bank lending: A matched bank approach. Journal of Financial Intermediation, 22. DOI:10.1016/j.jfi.2013.06.003.

Chiuri, M. C., Ferri, G., \& Majnoni, G. (2002). The macroeconomic impact of bank capital requirements in emerging economies: Pase evidence to assess the future. Journal of Banking \& Finance, 26. DOI:10.1016/S03784266(01)00267-9.

Committee on the Global Financial System (CGFS) (2010). Macroprudential instruments and framework: a stocktaking of issues and experiences. CGFS Papers 38, Bank for International Settlements.

Del Giovane, P., Eramo, G., \& Nobili, A. (2011). Disentangling demand and supply in credit developments: A survey-based analysis for Italy. Journal of Banking \& Finance, 35(10). DOI:10.1016/j.jbankfin.2011.03.001.

Dell'Ariccia, G., Igan, D., \& Laeven, L. (2012). Credit booms and lending standards: Evidence from the subprime mortgage market. Journal of Money, Credit and Banking, 44(23).

Dewatripont, M., \& Tirole, J. (1994). The Prudential Regulation of Banks. Cambridge: MIT Press.

Disyatat, P. (2010). The bank lending channel revisited. BIS Working Papers. No 297

Freixas, X., Rochet, J. (1997). Microeconomics of Banking. Cambridge: MIT Press. 
Gambacorta, L., \& Mistrulli, P. E. (2004). Does bank capital affect lending behavior? Journal of Financial Intermediation, 13. DOI:10.1016/j.jfi. 2004.06.001.

Gambacorta, L., \& Marqués-Ibáñez, D. (2011). The bank lending channel. Lessons from the crisis. Working Paper Series No 1335/May 2011, European Central Bank.

Hancock, D., \& Wilcox, J. A. (1994a). Bank Capital and the Credit Crunch: The Roles of Risk- Weighted and Unweighted Capital Regulation. Journal of the American Real Estate and Urban Economics Association, 22. DOI: $10.1111 / 1540-6229.00626$

Hancock, D., \& Wilcox, J. A. (1994b). Bank Capital, Loan Delinquencies, and Real Estate Lending. Journal of Housing Economics, 3. DOI: $10.1006 /$ jhec. 1994.1004.

Hancock, D., \& Wilcox, J. A. (1997). Bank capital, Non-bank Finance, and Real Estate Activity. Journal of Housing Research, 8.

Hancock, D., \& Wilcox, J. A. (1998). The "Credit Crunch" and the Availability of Credit to Small Business. Journal of Banking and Finance, 22(6-8). DOI:10.1016/S0378-4266(98)00040-5.

International Monetary Fund (IMF) (2011). Macroprudential Policy: An Organizing Framework. Paper prepared by the Monetary and Capital Markets Department. International Monetary Fund.

Jackson, P., Furfine, C., Groeneveld, H. Hancock, D., Jones, D., Perraudin, W., Radecki, L., \& Yoneyama, M. (1999). Capital Requirements and Bank Behaviour: The Impact of The Basle Accord. Basle: Bank for International Settlements.

Kishan, R., \& Opiela, T. (2000). Bank size, bank capital, and the bank lending channel. Journal of Money, Credit, and Banking, 32.

Kishan, R., \& Opiela, T. (2006). Bank Capital and Loan Asymmetry in the Transmission of Monetary Policy. Journal of Banking and Finance, 30. DOI:10.1016/i.jbankfin.2005.05.002.

Labonne, C., \& Lame, G. (2014). Credit Growth and Bank Capital Requirements: Binding or Not? Working Paper https://www.banque-france.fr/fileadmin/user upload/banque_de_france/Economie_et_Statistiques/Credit-growth-and-bankcapital-requirements-binding-or-not.pdf.

Lenart, Ł., \& Pipień, M. (2013). Almost Periodically Correlated Time Series in Business Fluctuations Analysis. Acta Physica Polonica, 123(3).

Mora, N., \& Logan, A. (2012). Shock to bank capital: Evidence from UK Banks at Home and Away. Applied Economics, 44 (9). DOI:10.1080/00036846.2010.537 $\underline{639}$.

Neuberger, D., \& Rissi, R. (2014). Macroprudential Banking Regulation: Does One Size Fit All? Journal of Banking and Financial Economics, 1(1). DOI: 10.7172/2353-6845.jbfe.2014.1.1. 
Olszak, M., Pipień, M., Roszkowska, S., \& Kowalska, I. (2014a). What drives heterogeneity of procyclicality of loan loss provisions in the EU? Faculty of Management Working Paper Series 3/2014. Retrieved from https://ideas.repec.org/p/sgm/fmuwwp/32014.html.

Olszak M., Pipien M., Kowalska I., \& Roszkowska S. (2014b). The Effects of capital on bank lending of large EU Banks? - the role of procyclicality, income smoothing, regulations and supervision. Faculty of Management Working Paper Series 5/2014, Retrieved from: papers.ssrn.com/sol3/papers.cfm?ab stract_id $=2543675$.

Olszak, M., Pipień, M., Roszkowska, S., \& Kowalska, I. (2016). What drives heterogeneity of cyclicality of loan loss provisions in the EU? Journal of Financial Services Research. DOI 10.1007/s10693-015-0238-6 (Forthcoming).

Peydró, J.-L. (2010). Discussion of " The Effects of Bank Capital on Lending: What Do We Know, and What Does It Mean? International Journal of Central Banking. December.

Peek, J., \& Rosengren, E. (1994). Bank real estate lending and the New England capital crunch. Journal of American Real Estate and Urban Economics Association, 22. DOI: 10.1111/1540-6229.00625.

Peek, J., \& Rosengren, E. (1995a). The capital crunch: Neither a borrower nor a lender be. Journal of Money, Credit, and Banking, 27.

Peek, J., \& Rosengren, E. (1995b). Bank regulation and the credit crunch. Journal of Banking and Finance, 19. DOI:10.1016/0378-4266(94)00148-V.

Peek, J., \& Rosengren, E. (1997). The International Transmission of Financial Shocks: The Case of Japan. American Economic Review, 87(4).

Peek, J., \& Rosengren, E. (2000). Collateral Damage: Effects of the Japanese Banking Crisis on Real Activity in the United States. American Economic Review, 90(1).

Roodman, D. (2009). Practitioners Corner: A Note on the Theme of Too Many Instruments. Oxford Bulletin of Economics and Statistics, 71. DOI: 10.1111/j.1468-0084.2008.00542.x.

Valencia, F. (2008). Banks' Precautionary Capital and Credit Crunch. IMF Working Paper WP/08/248.

Van den Heuvel, S. J. (2009). The Bank Capital Channel of Monetary Policy, Federal Reserve Board, Working Paper.

Van den Heuvel, S. J. (2011). Banking Conditions and the Effects of Monetary Policy: Evidence from U.S. States, Federal Reserve Board, Working Paper.

Volk, M., \& Trefalt, P. (2014). Access to Credit as Growth Constraint. Journal of Banking and Financial Economics, 1(1). DOI: 10.7172/23536845.jbfe.2014.1.2. 

